\title{
Dreaming of Others
}

\section{Carpentaria and its Critics}

\section{ALISON RAVENSCROFT}

LA TROBE UNIVERSITY

A nation chants, but we know your story already.

Alexis Wright, Carpentaria ${ }^{1}$

Nonknowledge or invisibility is not registered as the wavering and negotiations between two certainties, two meanings or positions, but as the undermining of every certainty, the incompleteness of every meaning or position.

White critical efforts to make meaning of Alexis Wright's Carpentaria have sought to anchor it to the big names among white Australian novelists. ${ }^{3}$ Such moves presume to make Wright indebted to these literary masters, assessing the significance of her text by its proximity to theirs. Frank Hardy's name is frequently evoked and so is Patrick White's; Xavier Herbert's name is repeated with the frequency of a nervous tic, one critic going so far as to suggest that Carpentaria's 'subversive high-spirited vernacular voice' might have been learnt from Herbert. ${ }^{4}$ White creativity appears in 
these critics' eyes as if it were the original creativity, the inventive one, the prototype. 5 These moves are surely another way of saying 'but we know your story already ... because it is our own'.6 They are moves that refuse the text's unfamiliarity, its strangeness to a white reader. ${ }^{7}$

Despite this recourse to white Australian literary traditions as marks against which to measure Carpentaria, these critics nevertheless remain at a loss: they 'just don't know' what to make of it, they are 'lost in the reading'. 8 The first familiarising move has not worked after all: neither text nor reader can be held on course, and so new moves are made. One move is to blame the author who 'cannot resolve the multifarious issues she sets running', implying that she should provide such resolution, that an unresolved and irresolvable text is a failure rather than an accomplishment. ${ }^{9}$ I'll go on to critique such a wish to find decidability in another's text but there is another move I'd like to discuss first. This is the very popular move to fix the text within the constraints of magic realism, a move that provides a vocabulary through which the novel can be read as 'dreamscape' 'magic', 'an indigenous magic realism'.10 This is yet another way of saying 'but we know your story already, its very form is our own', for magic realism is not a form of writing that arises in another's culture, as is so often claimed: it is very much the product of a certain white Western critical strategy. As Stephen Slemon once warned: 'the established systems of generic classification are complicit with a centralizing impulse in imperial culture' and the concept of magic realism might be one example. It threatens, he argued, 'to become a monumentalizing category for literary practice', offering 'a single locus upon which the massive problem of difference in literary expression can be managed into recognizable meaning in one swift pass'.11

What are the literary practices and histories to which Australian critics refer when they produce Indigenous-signed texts as magic realist? It quickly becomes clear that magic realism has been taken up in the name of literary postcolonialism's interests in the possibilities of reading and writing difference between the coloniser and the colonised. Indeed the critical production of magic realism now reads like a synecdoche for debates in postcolonial theory, exercising that body of theory's preoccupations with questions of hybridity and liminality. ${ }^{12}$ It is equally clear though that, in the end, the difference that is insisted upon in one moment is allowed 
to fall in the next. In Australia, as elsewhere, the strategy becomes one more moment in the production of another as a (lesser) version of oneself.

The term magic realism was coined by Franz Roh in Germany in 1925 to describe his vision for a new post-expressionist art, where the art would give representation to a subjective experience of reality, a reality that is amplified until its own so-called magic appears in the work of art.13 Roh's idea arose historically in the context of psychoanalysis and its interests in visibility and invisibility, in what can and cannot be brought into language, into knowledge. Like psychoanalysis, it is concerned with division and doubleness within any one human subject, where what Roh has called magic is always another aspect or experience of a psychic reality. It is that part of reality that hovers around, or palpates behind, what can be discerned. What Roh hoped might be made to appear in a new art as magical or strange is not another's reality, then, but always one's own-recalling Freud's insistence on the uncanny as the constitutive strangeness that is not exterior to the subject but within. ${ }^{14}$ Roh hoped for an artistic practice that could point to that part of subjective reality that escapes representation, this magic that falls from view and is perhaps felt rather than seen, an atmosphere one might say; a part of subjective reality that artistic practice might be able to point to by, for instance, figuring fragmentations of the visual field, or in certain distortions and condensations in patterns of darkness and light, in shadow and aura.

These hopes and possibilities are foreclosed, however, in most contemporary literary critics' mobilisations of magic realism. The term tends now not to be taken in Roh's sense of art that represents the magic of so-called reality, the very subjective strangeness of one's own psychic reality. Instead, 'magic' and 'realism' are taken to be two distinct, even oppositional, representational codes at work in a text and referring to two distinct worlds or cultures. These worlds are now keenly associated with the world of the coloniser on one hand and the colonised on the other. Unsurprisingly, the so-called magic falls on the side of Indigenous colonised subjects and so-called reality remains on the side of the colonisers.

In postcolonial literary criticism, gestures are always made towards difference, and the word 'dialectic' runs through this criticism like a talisman that could ward off charges of neoimperialism. But, as we'll see, these gestures towards 
difference and the dialectical turn out to be merely moments of deferral in the course of a 'self-same' argument whereby others' reality is produced as if it were a version of the colonisers' own, only a lesser one: less rational, less logical. The arguments eventually arrive at the point they are supposedly contesting: that the other's understanding of reality is a poor one, it is 'subeducated', in the words of one critic, it is naïve and fantastic, it is based in beliefs in the mythic and magical. ${ }^{15}$ The doubleness of a psychic reality which for Roh, after Freud, always has its own 'magic' within it is now arranged across two fields, with magic and its correlatesdream, delusion, irrationality_appearing in the field of the other.

In readings that produce Carpentaria as a magic realist text there is just this recuperation of the binary that associates Indigeneity with magic, irrationality, delusion and dream, and whiteness with realism, reality and rationality, and with consciousness, a wakeful state-despite these critics aiming at something else. Such an arrangement of dream and reality, sleep and wakefulness, across a colonisercolonised divide recalls arguments that Patrick Wolfe has made about the meanings associated with the term Dreamtime as it was conceived-we might say inventedby anthropological discourse. ${ }^{16}$ This discourse made an affinity between 'Aborigine' and 'dreams', where dream was understood to be a condition associated with sleep, or unconsciousness rather than with what might also be called (again, in English) Indigenous Law. Wolfe shows us how this coupling of 'Aborigine' and 'dream' in the Australian colonising context made for the dispossession of Indigenous peoples by taking them out of historical time and place: they were 'either effaced from the land or assimilated to it'. ${ }^{17}$ So, what is at stake for contemporary literary critics who, via the trope of magic realism, once more make an association between Indigeneity and dream? And, how might whites read differently so that our doubleness and division remain, so that our own magic, dreams and delusions might make their appearance?

What follows is, first, a more detailed critique of so-called postcolonial magic realism in which I point to critics' refusal to allow markers of difference in texts to be significant; indeed, to signify at all. Instead, there is a habit of skipping over these places where differences are inscribed as if they were not there at all. There are some differences that are just too much, it seems. Second, I propose reading Carpentaria through a different paradigm, and this is the paradigm of radical uncertainty, an impossible dialectic. ${ }^{18}$ In this might lie the beginnings of another 
reading practice, one that allows Carpentaria its difference, its strangeness, and which points to the necessary estrangement of its white readers. This is not to refuse the beauty of the text and the pleasures it offers but to suggest a reading practice that sits still with this beauty and bears its enigma. Third, I look at those readings by white critics that would have this novel as offering a white reader an opportunity to acquire new knowledge about Indigenous Law. Of these readings we might ask in what sense a white reader could be said to know Indigenous Law, and how would she ever distinguish it from this text's huge, generous, imaginative playfulness?

I do not argue that this particular text, Carpentaria, escapes writing's limits or that its author, because she is Indigenous, enjoys absolute or perfect vision. The argument, instead, is that for each of us there are limits to the powers of sight and knowledge, although whiteness invites its subjects to forget this and to believe instead in our own powers of perfect vision. If white subjects are canny enough, smart enough, patient enough, so the fantasy goes, we will be able to see what our others see, know what they know. From such a 'white' subject position, from the position that Carpentaria's white critics take up for instance, we can be tempted to approach another's knowledge as if it were always and in all ways accessible. Here, I look at white critics of this Indigenous-signed text who have mistaken the meanings they can make of it for truth, for complete knowledge, for 'reality' itself.

\section{-CAn BLACK People fLy?}

What is magic and what is reality, and by what representational codes will we recognise these? How will readers know these different worlds and representational forms when they come across them in a text? Perhaps the questions might better be posed: whose magic, whose reality? Critics have warned against the effects of using the term magic realism too freely because of the ways in which there is the risk that audiences among the Western world will read other culture's reality as magic. Arguing against reading magic realism as magic in the Western sense, Roberto Gonzales Echevarría for instance has said of magical realism that it has 'as its source material beliefs or practices from the cultural context in which it is set', what Maggie Bowers has called, after Echevarría, 'ontological magical realism', where what might appear to a Western reader as magical or marvellous are qualities that are reality to 
the population out of which the text was produced.19 They are 'ontologically necessary to the region's population's "vision of everyday reality"'.20 This kind of argument points out that what is taken by a white reader to be magic in these texts might not be so for the world of the novel or in the world of the author. This is what I take Gabriel Garcia Marquez's refusal of the term magic realism to mean: it did not, he maintained, describe his own work at all, despite his work being cited by critics as the very cornerstone of the genre. Instead, Marquez insisted that he was a realist writer: 'I believe that in Latin America everything is possible, everything is real'.21 The so-called magical is for Garcia Marquez a subjective representation of a social reality. Literary critics such as Lois Zamora and Wendy Faris, too, point out that:

Texts labeled magical realist draw upon cultural systems that are no less 'real' than those upon which traditional literary realism draws-often nonWestern cultural systems that privilege mystery over empiricism, empathy over technology, tradition over innovation. Their primary narrative investment may be in myths, legends, rituals. ${ }^{22}$

But while Zamora and Faris, like other literary critics, point out that what is magic in magic realist texts might not be so for the world of the novel or in the world of the author, at the same time their argument tends to fall away from this claim, it is unable to insist itself. As I've already said, gestures towards difference turn out to be only pauses in the course of a 'self-same' argument. They are merely deferrals. The arguments tend to eventually arrive at the same point they are supposedly contesting: that the other's understanding of reality is only naïve, fantastic, mythicit is 'magic' after all. A gesture is made to the possibility that what appears as magical to the Western critic might be reality to his or her others, but the narrativity that these others pursue turns out to be, in the minds of these critics, only a tale, a myth, a legend. These very terms, these genres, are the Western critics' own, and are associated in these critics' discourse with magic, fantasy and the supernatural. ${ }^{23}$ Then, as Zamora and Faris have done here, the 'non-Western' cultural forms out of which the narratives are said to arise tend to be characterised as mysterious, too, empathic and traditional against an empirical, technological and innovative West, making the other culture's reality mysterious-even to itself.24

On this question 'whose magic, whose reality?', Toni Morrison has made some claims that are worth taking a little time to consider here, not least because of 
the anxiety they seem to arouse among some of her white critics. Morrison claims that among African-Americans there are ways of knowing that might fall into the magic or superstitious in the eyes of white American readers. African-Americans 'are a practical people but within that practicality we also accept what I suppose could be called superstition and magic. Which is another way of knowing things. ${ }^{25}$ Morrison's insistence (much like Garcia Marquez's, or indeed Alexis Wright's) that she aims to represent 'reality' in its complexity rather than simply referring to 'magic' and superstitions, causes discomfort among many of her critics. ${ }^{26}$ The distance that is installed by Morrison's own words-'what I suppose could be called superstition or magic'-is collapsed. Morrison's own reservations about the suitability of these words 'superstition' and 'magic' are closed over, and 'superstition' and 'magic' are reinstated as distinct from 'reality'. The white Western critics' reality has become the only one.

I'd like to tease out an example of Morrison's critics' refusal to take her at her word, even while claiming to do so. P. Gabrielle Foreman insists on interpreting as mythic Morrison's Songs of Solomon where men and women have the power to fly. There is a surprising frequency with which this particular story is referred to by literary critics, as if there might be something about the story that disturbs more than might be admitted in accounts of it as 'merely' magical, or as a rhetorical move. Foreman insists that this story be read within the mythic and magical even while she offers a quotation from Morrison which suggests something quite different. Morrison herself says that if this story of men and women flying 'means Icarus to some readers, fine; I want to take credit for that. But my meaning is specific: it is about Black people who could fly.' White readers' own story, the myth of Icarus, is taken by these readers to be the prototype on which Morrison's story is based, whereas for Morrison, whether her story rightfully belongs in the genre of myth at all is rather more doubtful. 'Flying', she says, 'was one of our gifts. I don't care how silly it may seem ... it's in the spirituals and the gospels. Perhaps it was wishful thinking ... but suppose it wasn't?'27 There are possibilities that Morrison seems prepared to consider-that flying once belonged in an African-American reality, although perhaps not her own.

Morrison's claim, then, that Black people could fly becomes quite enigmatic: what can she mean? And what can the magic/realist divide do with this sort of 
claim? Returning to Stephen Slemon on magic realism: he insists that the importance of magic realism for a postcolonial project lies in its refusal to resolve or translate one representational system into another. Realism and fantasy are 'each working toward the creation of a different kind of fictional world from the other'.28 Slemon argues for an incompatibility between these fictional worlds that prevents either coming fully into being, 'each remains suspended, locked in a continuous dialectic with the "other", a situation which creates disjunction within each of the separate discursive systems, rending them with gaps, silences and absences'. ${ }^{29}$

Surely Slemon's point would lead us to ask: in what nexus of signification is the notion of men and women 'flying' given its meaning? In what other world of meaning does this possibility arise? And how would we read across the time and space between our world and this other one? Surely we can't. The claim that Black people could fly belongs to another story than the one Morrison's white critics can read, and of that story, that scene to which 'flying' belongs, all they can see is that signifier-'flying'. We might say that the signifier itself flies, it floats like the skull in the foreground of Holbein's The Ambassadors. ${ }^{30}$ To name it as 'magical', or as deluded, as wish-fulfilment, as fantasy, is to refuse the division in the visual field, which is to say it is to disavow the critics' own division: it is to disavow the incompatibility between worlds that Slemon insists on. It is to refuse a world of meaning, another story, which remains inaccessible to the white critic, indeed as it may remain inaccessible to Morrison herself. The difference between Morrison and her critics is that Morrison is prepared to consider that there are other worlds of meaning and she invites us to 'just suppose' with her. These words are ignored by Foreman, written over, as if the utterance had never been made. The gap in the white critic's knowledge is closed over.

Similarly, Maggie Bowers, after a discussion of 'ontological magical realism' drops realism out of her interpretation of Morrison's story of flying men and women, and the story becomes only magic or mythic again: 'Her magical realism includes characters who can fly back to Africa when they die. This was a commonly known myth amongst African American slaves.'31 What would happen if that word 'myth' were dropped out here? Bower's statement would suddenly be made bolder, more epistemologically challenging, and closer to Morrison's own claims. It would become: 'This was commonly known amongst African American slaves'. After all, 
this is what Morrison says. Her claim is not about a myth; she claims that it was the power of flight that was known and not a myth about the power of flight. This would be to follow through the logic that these critics of magic realism have themselves established: that one's reality is not another's; that there are other ways of knowing. It would be to point out that Maggie Bowers is not necessarily or exclusively occupying the same world of meaning as Toni Morrison and that she is certainly not occupying the same world as the Africans about whom Morrison writes.

Morrison, like Alejo Carpentier and Gabriel Garcia Marquez before her, has been condemned by some critics for these kinds of propositions. ${ }^{32}$ Morrison's insistence on a distinctly different African-American reality, subjectivity, indeed corporeality, has provoked particularly powerful antagonisms. She has been accused of participating in her own cultural prostitution, ${ }^{33}$ inventing an 'enchanted village called blackness', ${ }^{34}$ and surely many readers will find the notion of Black men and women taking to the skies and returning in this way to Africa as entirely fanciful. What is just as clear, though, is that a writer like Morrison might be aiming to put under strain white readers' assurance that they can decide what is real and what is magical, or whether it is a reality represented naturalistically and when it is figured in code.

While the magic-realist novel's subversive capacities lie for many critics in the pressures brought to bear on a hegemonic, colonial reality on one hand, and on realism as a naturalised mode of representing it on the other, this hegemonic reality is once more reiterated in the very assurance with which the real and the fantastic are determined by white critics as being across two cultural locations. What would be more productive would be to return to the idea of the 'magical' and 'reality' as subjective experiences that are available in any cultural location. ${ }^{35}$ As Freud said, there is only one reality, and this is a psychic one, where 'fantasy' and 'reality' are one and the same. But the idea of magic realism as an aesthetic form that might give expression to the division and doubleness of the subject is precisely what drops from white critical efforts to read Carpentaria as magic realist. Instead, reality and magic are once more divided between ourselves and our others, disavowing the white subject's own doubleness, her own 'magic', her own strangeness to herself. 
Carpentaria effects its own resistances against the exclusive coupling of 'dream' and 'magic' with 'Aborigine'. To start with, it is populated with white men and women who are irrational and illogical. They are naïve believers in their own nonsense, where newfound legends and lores, folktales, lullabies and children's verse, miracles and creation stories stand in for knowledge of their own history and of the country around them. They believe for instance in 'an original God who had come along with all the white people, who created everything for them'. ${ }^{36}$ These are men and women who are looked upon in wonder by the Aboriginal men and women for being historyless: their white worldview is a failure of history and of origins, theirs is a timelessness, of men and women wandering without recourse either to origin or destination, without culture, song, or sacred places, ghostly men and women arriving with no past they could remember. ${ }^{37}$ When a white man arrives in their midst in a most unusual way, walking in across tidal mudflats after a storm, coming with no name and no memory, these white folk recall the arrival of their own forebears. This man who will in the end be known by the name of Elias Smith recalls ' $[\mathrm{t}]$ heir original forebear, a ghostly white man or woman, simply turned up one day, just like Elias. On the scale of things, their history was just a half-flick of the switch of truth-simply a memory no greater than two life spans.' 38

The white men and women watching Elias coming in from the sea wonder what he is. Is he, after all, a man, or something else, equally believable to their minds: 'An angel carrying the message of the one they called the Almighty? A ghost, spirit, demon or sea monster?'39 In the eyes of the white citizens, the arrival of this man is a vision of 'a marvellously hideous other kind'. They believe they are 'witnessing the emergence of an aquatic aura, a God-sent water angel', and 'downright proper, respectable Uptown women could not escape the spell the mariner had cast on them'.40

Here, whites desire to find magic in the other, they seek it out, they produce the supernatural in the 'other kind' so as to bring it into their everyday world. They hold hopes of their lives being enchanted by the other. Out of their own incapacity to acquire a working knowledge of the world they find themselves in-they cannot read the weather, for instance, or fish the seas-they read others' knowledge and skills in the register of magic. So, Norm Phantom's powers to navigate great bodies of water, to know stars and storms, the currents of the air and the sea, to know 
where great schools of fish are still to be found: these powers cannot be imagined by the white citizens of Desperance to be based in rationality, in acquired and practised intelligence. It is their own rationality that fails.

The white citizens of Desperance are captured by their own dreams and delusions; they are 'netted'. They believe that the town is protected by an invisible net:

made up of prayers and god-fearing devotion-a protective shield, saving the town from a cyclone ... every November, at the onset of the Wet, at night, when some of the Council men could be seen congregating in secret. You knew the net was being drawn, because you could see the mysterious flashing of torchlight in the long grass. In the Pricklebush, everyone stopped to listen when the bush creatures became silent. Crickets and frogs were the guardians of the night for generations of Pricklebush folk. The old people said, Don't worry. They explained the men were checking their magic nails in the fence posts in case anyone was stealing them. ${ }^{41}$

Among the whites there are those who 'could tell you the stories of how they had been taken away for weeks on metallic-disc spacecraft with red lights flashing across the sky, and who knows, they said when they came back, if aliens were invading the whole countryside'. 42 The difference in 'dreaming' between whites and Aborigines in Desperance is noted by the Pricklebush mob, too. Where the 'Pricklebush mob saw huge, powerful, ancestral creation spirits occupying the land and sea moving through the town, even inside other folk's houses, right across any piece of the country', they see the white citizens as having 'puerile dreams of stone walls, big locked gates, barred windows, barbed wire rolled around the top to lock out the menace of the black demon'.43 The Pricklebush look on in disbelief at the Uptowners who not only believe in these strange dreams of their own making, but believe they can be 'masters of their own dreams'.44

And, crucially, this novel not only points to its white protagonists' wish to find magic in others, and so enchant their own world, but implicates those white readers who also possess a similar desire. A white reader and not only the white residents of Uptown might find herself drawn to the others' magic, desiring to find the magical as resting in her cultural others-lured, as to a hook, by hopes of finding magic and the dream in the other, saying it was always there, that it was written for 
us, that it is just there, on the page. Many white readers have delighted in making others the repository of magic, wanting to believe. Carpentaria, then, is a text that inscribes a white reading practice into its narrative: it is we who are pointed at and challenged. 'Do you', the text seems to ask, 'dream of others and then say it is their fantasies rather than your own?' When a white reader determines the text's placement in her own genre of magical realism, what is this but a determination to read her own bewilderment as the other's magic?

-A POETICS OF UNCERTAINTY

But Carpentaria does more than reverse the colonialist distribution of rationality and irrationality between white and Aboriginal. It does more than tell tales of white irrationality on one hand and Aboriginal logic and intelligence on the other. It accomplishes its political work through an aesthetics of uncertainty, a radical, irresolvable equivocality in language and form. This is not a dialectic that can be resolved: there is no unitary resolution, no dialectical synthesis. It instead raises, for me as a white reader, an aesthetics reminiscent of modernism rather than magic realism. This is an aesthetics that recalls James Joyce, whom Alexis Wright admires, rather than Herbert whose novels she 'has no time to read; she is too busy learning from other people'. 45

Carpentaria is over five hundred pages of labyrinthine narrative that opens onto one scene and then onto another, one story folded between others as if in parenthesis. Past and present intermingle in the space of a page or even less: time expands into the cracks and crevices of the here-and-now, bringing with it a proliferation of images and sounds that belong now to a man's broken marriage and now to land woman devil Gardajala, ${ }^{46}$ now to a dead white man being returned to the giant old gropers in their secret place in the deep seas, now to a small boy whose mother Hope has been dropped while still alive from a helicopter at a great height over water. Carpentaria is a novel so full of images it will take many returns to its pages before a reader could boast of more than a slight acquaintance. So, how to keep reading and rereading this text that surely exceeds a white reader's easy knowing? How to resist the call to bring this novel into the white Australian literary canon on one hand, or into an imperialist magic realism on the other? What other ways to read Norm Phantom's journeys through stormy seas into country populated 
by yinbirras, among them toothless old women 'dressed in crumpled leaves, bush blossoms, tangled strands of grasses'; ${ }^{47}$ or his son Will's experience in the flooded Desperance hotel in a cyclone, visited by an old lady in a knitted beanie and floral dress who 'had every right to grab her turn in a countryman's dreams'?48 I ask myself again, like an incantation: how to 'make sense' of this? How to read?

Clearly, not within the monologic of conventional Western literary realism, on this point there would be few dissenters. There is, for instance, no easy narrative outline that I could provide that would be at all supportable. Carpentaria exceeds the narrative elements I could name and order, and it does this crucially through its form and language. To my reading, Carpentaria puts into effect an aesthetics of uncertainty; in its language and form there is a radical doubleness, a poetics of equivocality. It is 'unpinnable'. It inscribes different worlds and representational modes in the space of a few lines or phrases; it brings different objects, different worlds, into such close proximity that their placement in a rational or magical mode is undecidable. It makes the very division into magical and rational, living and dead, body and country undecidable - at least for this white reader. This is not an undecidability that resides (only) in the Aboriginal protagonists, as some reviewers have suggested: it is not just Normal Phantom or his son Will who can't always tell what is living and what is dead, what is dream and what is waking, where one's own mind ends and another's begins. ${ }^{49}$ This undecidability is produced in me, too. The conventional European arrangements of objects into reality and fantasy, interiority and exteriority, country and culture, earth and body-these can no longer hold, and the text moves and morphs, it shimmers. This movement, this doubleness, troubles my sense of knowing: it is the 'hinge' through which another scene opens, one I cannot see/hear/know, one I cannot signify. It belongs in another story than the one I can know or imagine.

To show something of this, we can look to the musicality of the text as a starting point. It is from this that we might be able to tease out what I'm suggesting might be the text's uncertainty, its irreducible doubleness. For there is an impossible doubleness to its music, at least as it sounds-and fails to sound-to my senses. The text brings sounds I can hear-opera, country and western, choral music-into proximity with sounds I cannot hear even as I am told they are there to be heard. I cannot hear Glory! Glory! from the gills and scales of fishes. I cannot hear opera or 
sacred music issuing forth from the country itself. Although I can recognise each of the elements in a scene, I can't bring them together into the one scene. They remain unassimilable to each other. The text seems to require of me that I hold the two together rather than resolve them, holding them as distinct, in a relation of tension.

Music is an important part of Carpentaria's form. The text opens with music, and music continues to its very close, ranging in tone and timbre, mood and form. The novel's epigram is: 'A nation chants, but we know your story already. The bells peal everywhere. Church bells calling the faithful to the tabernacle ... ' The novel closes with another kind of song altogether: 'It was a mystery, but there was so much song wafting off the watery land, singing the country afresh ...50 The country sings, the crickets sing, wind and water, birds and fishes, humans too are all moved to sing, to give voice to ... what? It's hard for me to say. At times Carpentaria is a libretto, at others a requiem, at others it follows the lyrics and rhythms of country and western, and then again it refers to sounds that elude me: the country's own song.

Then there is the Irish priest in his old black souped-up Valiant driving in a storm across a flooding plain, who turns his car's cassette player to full volume and triumphant trumpets and the Philadelphia Tabernacle Choir flow out into the surrounding saltbush. ${ }^{51}$ Pulled over by the local mine's security guards, he addresses his antagonists in furious speech accompanied by the 'heavenly voices in a Te Deum of three massed choirs'. Another choir occupies Norm Phantom's fishroom where he practises his taxidermy, turning dead creatures into exquisite jewels. Secretly, Norm himself believes these miracles are not his own work, but the work of some God who uses 'the room as an experimental studio, a type of exposé for life in the decaying world, where the air smelt like a beach'.52 Into this room, the winter winds blow:

south-easterly in weekly rhythms after midnight. Like nobody else, Norm loved the grand old composer, the rapturous melodies which swam along the tin walls of the corridor from the house to the fishroom. The music arrived in the middle of the night and tapered off after midday ... Norm sang Gloria, alongside the old composer conducting his mass choir of crickets that sang Glory! Glory! In time with the rattling walls. The crickets, 
part of the fishroom's metamorphosis, lived in the dark, musky, fishsmelling environment. ${ }^{53}$

And Norm's resurrected fish, gleaming among the rafters where he has hung them, 'sang eerie songs in shrilled, mezzosoprano voices that floated out of their mouths from the crickets' hidden nests, from deep inside the fishes' horsehair bellies'. ${ }^{54}$ If all texts are tissues of quotation, then here we have a selection of musical forms that, for all their familiarity, are nevertheless made scarcely legible, or audible because of their arrangement. They are brought into an arrangement that unsettles my own sense of knowing.

Then there is Big Mozzie Fishman singing country and western to soothe and settle himself and his followers in his 'never-ending travelling cavalcade ... bringing a major Law ceremony over the State border'. 55 'Their convoy continued an ancient religious crusade along the spiritual travelling road of the great ancestor, whose journey continues to span the entire continent and is older than time itself'. The writing at this point takes on the feel of Fishman's tune:

In the middle of the day, the vehicles were travelling along a narrow, hilly road, twisting like a goat track out of Mozzie's fishing nightmares. This stretch of road always caused Big Mozzie to break into nervous singing with a great deal of soul to the spirits. 'Goodbye Joe, me got to go, me oh! Myo! Me got to go for the codfish ladies down the Bayou.' Seriously, he told Will Phantom, a young man in his mid-twenties, who was travelling in the same car right next to Big Mozzie as his driver, he was a living expert on every Hank Williams song known to mankind. Older convoy members pretended this was true. It saved the peace. However, they knew, he knew, he never remembered the lyrics of any song, and simply invented new words to suit himself. But why not! 'The son of a gun, hey, Will?' And he broke into a jitterbug, singing on about some place as if he knew where it was: 'A buzzin, having fun down the Bayou.'56

I am puzzled not only by song but by the entire scene. To my eyes, the image of Mozzie Fishman and his men brings with it a mix of medieval Christian crusades and indigenous practices, and puts them altogether in a convoy of a hundred 1980s Falcon sedans and Holden station wagons, a 'long line of battered old cars heavily coated in the red-earth dust of the dry country ... leaving in their wake a haze of 
petrol fumes and dust'.57 This is strangely beautiful, an evocation of persistence in motion, at once full of earnestness and humour, of the musicality of a circus and the violence of a vocation, Christic images of the sick being healed on one hand, and Fishman's refusal to perform any miracle of the loaves and the fishes on the other; and running through it all is surely the cold-edged reality of political resistance, all moved, like the cavalcade itself, by the engine of something enigmatic-to me, at least. Perhaps it is driven by the inventiveness and determination of these religious devotees who double as mechanics with artisans' hands and genius minds, fashioning tools as well as spare parts from nature, and so 'all of these vehicles survived over thousands of kilometres of the country's hardest rock and gravel'.58 I do not know how to distribute power and pathos, humour and forcefulness among the elements of such a scene. Do I show myself as a fool to take any of it seriously; am I misreading the significance of what might in fact be a 'cult'?

To point to the musicality and indeed the triumphalism of the narrative is to risk failing to point to its tragedies and its insistent story of resistance. It would be easy to overlook, say, Norm's suppressed violence when faced with his hatred of the policeman Truthful who sexually abuses Norm's daughter. Truthful knows how to make 'Girlie scream for being mean to him. Well! She knew what she was asking for, he thought, if it was pain she wanted.'59 'The handcuffs in his pocket pressing into his groin aroused the sensation of good times ahead.'60 There are the three little boys, petrol sniffers, who die after being left to languish forgotten in a prison cell for a crime they did not commit. Then there is the torture of Kevin Phantom, the 'coon boy', by white men under white hoods. 61

He heard his bones break with a pain that forced him to open his shocksealed lips, and call out through the muffling bag to his father ... He was wet and hurt, and his arms, stretched out in front of him, they were being dragged off his body. His skin was burning, he was being skinned alive, pulled behind the car, its exhaust fumes choking his breath. ${ }^{62}$

It is tempting to resolve these different moods and rhythms of the text into two distinct registers. If we were to follow those critics who advise us to read Carpentaria within the genre of magical realism, the parts of the text that appear as wondrous, or theatrical or triumphant would fall to the magical and fantastic; and tragedy, loss, and violence to realism-this despite the claims made for the genre's 
dialectic between so-called magic and realist forms.63 If, as Slemon claims, the magical realist genre at its best offers a dialectic that points to the gaps and silences in each of the two representational forms, then in Carpentaria we might say that we have a text that inscribes an impossible dialectic: one that emphasises that these gaps and silences cannot be filled. This is the dialectic's impossibility: the dialogic necessarily fails to produce a whole. This might be the most threatening of possibilities for a white reader. That is, the endless movement that for Slemon is the dialectic never results in full knowledge. The dialectical is a recognition of the uncertainty of all knowledge. So, unlike the conventional trope of magical realism which ultimately resolves two worlds or forms, and beyond Slemon's important intervention in that tendency which nevertheless suggests a movement in a particular direction - that is, towards knowledge-instead we might think not of a continual movement between knowledges, not using one to fill in a gap in the other, but the gap in all knowledge. If this is true, whites cannot hope to look to another to fill in the gaps in their own knowledge, of themselves or their others. There are things an other knows (there are objects that are made) that we will never know/see/hear. The question of how to read, then, becomes this: how to bear such partial vision?

-'A TREE CAN ACT VERY STRANGELY, IF IT WANTS'

In prevailing white Australian discourses, Indigenous Law is still read as if it were a form of fiction, an infantile, naïve fiction holding no explanatory power. By 'fiction', I mean an unreconstructed notion of fiction as an act of the imagination that bears no truth, as against 'knowledge' held to be factual. Indigenous Law is read in this unreconstructed sense of fiction. It is translated as legend, or myth, or children's story; ${ }^{64}$ or as the Dreaming where Dreaming is taken to be the kind of dreaming one does on one's pillow, a fantasmatic distortion of everyday life without geographic or historical coordinates. ${ }^{65}$ Another's epistemologies are reduced to an irrational or primitive naivety, belief rather than knowledge, lore rather than Law.

For an Indigenous author interested in referring to the Law in her fiction, this kind of interpretation of Law poses peculiar problems. How will her figuring of the Law be read by white Australia? Does it once more risk being dismissed as fantasmatic, or naïve? This is especially so if the author is also attempting to figure 
distortion, the fantastic, the fabulous and the dream in her fiction as Wright seems to be doing in Carpentaria, for how would a reader distinguish such playfulness from representations of Indigenous Law if she already reads the Law itself as only a dream, a fantastic story of magic powers, a naïve story of origin? So, while one critic warns us against reading Indigenous-signed fiction ethnographically because, she says, there is no 'ethnic authenticity' in its pages, we might counter with another claim: that the danger might lie elsewhere, in white reading strategies that persist in producing other knowledges as already a kind of fiction. 66

Against the idea that Indigenous-signed texts cannot be read ethnographically and against, too, the idea of Indigenous Law as a naïve epistemology, Frances Devlin-Glass urges us to read Carpentaria as 'a powerful contribution to understanding of indigenous knowledge'.67 According to this critic, white readers can acquire new knowledge of Indigenous Law from the pages of Carpentaria. This new move-to read Carpentaria as a 'true representation' of Indigenous Law-presumably comes out of a desire to take seriously the claims made by Indigenous authors themselves that their texts are Aboriginal realism, say, or 'true story', or as Alexis Wright is quoted as saying of Carpentaria: 'It was the voice that Australians have never listened to. It's the voice of Aboriginal elders speaking about people and country, talking about what Aboriginal culture is, what it means and how it might work in the future'.68 And, for sure, the idea that Indigenous-signed texts might in some way inscribe Indigenous Law, where Indigenous Law itself inscribes sophisticated knowledges, is often too much for literary critics. Devlin-Glass's critical move also comes out of an explicit interest in what is an ethical necessity for a postcolonialist critic and that is to read Indigenous narratives not as primitive knowledge but, following anthropologists such as Deborah Bird Rose, as the complex encoding of ecology and natural history. ${ }^{69}$ Devlin-Glass wants white Australia to take Indigenous narratives very seriously-as important forms of knowledge.

So, why shouldn't whites read Carpentaria in the way that Devlin-Glass proposes? Why not read Carpentaria as a 'powerful contribution to understanding of indigenous knowledge', as a text that 'mobilises and modernises indigenous narratives of the Gulf of Carpentaria, in particular the multifarious Rainbow Serpent and associated mythological beings of the region'?70 After all, the 'great serpent' is 
represented on the book's cover in an image reproduced from the skin of Indigenous activist and Wright's countryman Murrandoo Yanner: this is his tattoo. The serpent is there in the opening pages where the narrator makes his claims that in a tidal river in the Gulf of Carpentaria, the great serpent lives still, its body taking breaths that are the size of tides. Its moods change the river's course, with its intake of breath it draws the tide inland, towards the gorges of a limestone plateau, and its exhalation turns the tide back to the giant water basis separated from the open sea by a folding-in of the mainland. This river snake is the ancestral serpent that still lives 'deep down under the ground in a vast network of limestone aquifers. They say its being is porous; it permeates everything. It is all around in the atmosphere and is attached to the lives of the river people like skin.' 71 This serpent:

came down those billions of years ago, to crawl on its heavy belly, all around the wet clay soils in the Gulf of Carpentaria. Picture the creative serpent, scoring deep into-scouring down through-the slippery underground of the mudflats, leaving in its wake the thunder of tunnels collapsing to form deep sunken valleys. The sea water following in the serpent's wake, swarming in a frenzy of tidal waves, soon changed colour from ocean blue to the yellow of mud. The water filled the swirling tracks to form the mighty bending rivers spread across the vast plains of the Gulf country. ${ }^{72}$

According to Devlin-Glass, this serpent is an 'expression of the Waanyi Rainbow Serpent' and the novel 'elaborates, from a Waanyi point of view, an understanding of the Indigenous sacred'.73 This Waanyi point of view emerges for her, she claims, out of her familiarity with Indigenous knowledges-she can recognise the Waanyi imagination and its representational forms by bringing these into proximity with ethnographic material not with the Waanyi as it happens but with the Yanyuwa, whom she says 'share songlines in the Gulf of Carpentaria with Waanyi, especially secret and sacred women's business and Rainbow Serpent ceremonies'. It is 'a legitimate manoeuvre' she claims, 'to read this Waanyi novel in the light of Yanyuwa material ... since they share Rainbow Serpent songlines, and in particular the stories of Bujimala and Walalu, the Whirlwind Serpent, both relevant in this novel' ${ }^{74}$ 
Well, is it? Who is it that has legitimated a move that collapses Waanyi and the Yanyuwa? Where does this legitimation lie? These questions, though, I have to put to the side. The question I can ask, the question I will insist on, is this: how would a white subject ever be able to read either Yanyuwa or Waanyi narrative, to read the country, to read skin and tattoo, to read the country as Waanyi might? To go back to arguments I have made elsewhere, how do we see, or know, or imagine, from a Waanyi point of view if we are not Waanyi? ${ }^{75}$ The answer that many white critics are offering is this: whites don't need to 'think Black', as W.E.H. Stanner once wished we might-itself an impossible and fanciful wish. Instead, whites can refigure Indigenous thinking as our own: in this formulation, our others' thinking is like ours after all, it is a shade of white. That is, we are called, by these critics, into a belief that we can push Indigenous knowledges into the shapes we can see, into the shapes of our own thinking.

To accomplish this, however, white readers must install themselves into the text, rewrite it so that it once more becomes another version of our own stories. So, for instance, Devlin-Glass is one of Carpentaria's critics who insists on likening Alexis Wright and Xavier Herbert, so that Wright's alleged insistence on the congruence of science and mythological knowledge is seen to be similar to Herbert's in Poor Fellow My Country. ${ }^{76}$ Xavier Herbert, Alexis Wright and by extension DevlinGlass can each stand in the same place in relation to Indigenous 'mythological' knowledge.

Devlin-Glass's approach is reminiscent of standpoint theory where researchers seek to position themselves in relation to their material: 'I need to position myself in relation to this material', she says. ${ }^{77}$ She has worked 'for over a decade with Aboriginal elders, mainly women, from a neighbouring community in the Gulf of Carpentaria, the Yanyuwa ... I've been instructed in women's business, most recently in 2004 for the purpose of proofing a women's ceremony grounding.' However, the so-called standpoint-the coordinates by which the researcher's position is known-are always the ones that are knowable, visible to the researcher herself. This is the paradox of standpoint theory. This method doesn't, cannot, aim at the researcher's blindspots, which are disavowed. The coordinates that one can name are always in the field of one's own making, the field one can see, the field that one's own epistemologies describe. Such a declaration of a position cannot render 
visible one's position in the field of the other. And, what standpoint is it that a white critic could possibly take up in order to understand what Alexis Wright says it has taken her a lifetime to understand, the stories her grandmother told about the Gulf country, stories about places and people and things: 'A person could be something else; a tree could behave very strangely, if it wanted to.'78 I wonder what a white reader can make of that.

My argument here is that Indigenous Law cannot be 'seen' from a Waanyi point of view if one is not Waanyi, and that time and again the Law falls out of the scene of white Western imagining, it falls out of the scene we can see or know. Indigenous Law remains as a fragment, distorted by the light cast by the scene we can see; in our scene it cannot appear. It makes no sense in a white Western epistemology, and at best its traces are translated into English, into modern Western discursive frames such as 'ecology' or 'natural history' or 'science'. That is, it is translated into our own nexus of intelligibility-a process through which Indigenous Law as an object of knowledge is made into a different object. So, rather than 'taking Wright's representations', as Devlin-Glass says-rather than seeing for instance river and cyclone as 'an expression of the Waanyi Rainbow Serpent'-we might better look at how this text positions a white reader in relation to these and other stories of Dreaming and Indigenous Law. Rather than presuming to know how the Rainbow is imagined by Yanyuwa, by Waanyi, by Alexis Wright, we might be better put to examining the limits of our own imagining.

Rather than reading Carpentaria as a resource from which we can know others-as ethnography purports to be, for instance- we might read it as a novel that presents a white reader with its own quite specific qualities of unknowability, and undecidability. We cannot read it ethnographically, but not for the reasons that Maria Takolander suggests, not because it has no 'ethnic authenticity' in its pages. We cannot read it for its ethnic authenticity because we could not recognise this socalled authenticity if it bit us. But as white readers, we do not need to read ethnographically to allow the Law a place in the critical production of Indigenoussigned texts. We do not need to know the answer that Devlin-Glass poses, for instance: 'Is this new rubbish-island a playful (and deeply serious) reformulation of Bralgu (or in Yanyuwa, Garrwa and Waanyi, called Jingkula), the "spirit land", located in an indeterminate place in the Gulf where the spirits of deceased people 
travel?'79 How could she or I know? And even if we were given an answer, would that mean that we would now know any more than we did before?

Rather, the Law might be better admitted into white readings as an enigmatic possibility, one that cannot be anchored to the meanings a white reader can produce. That is, the Law is very precisely unreadable to a white reader, and our efforts at translation must always fail. For, how do I know what it means to say not only that Indigenous Law is law in the sense of protocols that must be followed, the laws that order the social bond, but also the law of the country itself, forces to which all living things are subject, ${ }^{80}$ a conception of the Law as inevitable, irrepressible? ${ }^{81}$ My world and the world from which Indigenous Law emanates cannot be melded, to use Devlin-Glass's word, because they are incommensurable. We can't assume, as Devlin-Glass seems to do, that because the narrator uses the lexicon of the Indigenous sacred at one moment (Serpent, Spirit, Dreaming) and the lexicon of modern geology, meteorology and marine biology in the next that this represents a hybridisation of these respective epistemologies-or that the language of modern science is a translation of Indigenous sacred terms such as the Serpent-because the mobilisation of either lexicon is an act of translation, into English, of Indigenous knowledges. Whether the narrator speaks of the 'serpent' or of the movement of water through 'limestone aquifers', in either case he is translating Indigenous knowledges, including Indigenous Law, into English.

This is not to argue that because a white subject cannot know, for instance, Waanji cultural texts as a Waanji might that a white subject should not approach these; it is not to argue for that kind of silence between Indigenous and settler. It is important to keep moving towards Aboriginal culture, art and law, but this is a movement towards understanding rather than an arrival. This is to argue for knowledge as always provisional, not a thing one possesses but a position-a situation.

Indigenous-signed literary figuring of Indigenous Law presents a white reader with an anamorphotic form: that is, an object which we cannot see. For the Law cannot appear to us, it belongs to another scene than the one of our abiding, the one of our formation as subjects. In art-again, in The Ambassadors say, or in Roh's hopes for a post-expressionistic art practice-the unseeable is made to appear-as a fragment, an aura, an echo of another scene altogether. Art points to this other 
scene, it does not render it, it can only refer to it. It cannot be rendered: it cannot be seen, its existence can only be pointed to. This is one way of thinking about art: it is one way of thinking about Carpentaria: as art, as art that makes the gap in all knowledge, and crucially the gap in our own, appear, but as a gap. The holes cannot be filled.

It is very tempting to put anthropological discourses into proximity with a novel such as Carpentaria, as Devlin-Glass has done, and look for one-to-one correspondence: to look for the objects of knowledge from one world that will fill in the gaps in another. If we resist that temptation, though, ethnography and anthropology can offer literary critics something very important, and this is a sense of our own profound bewilderment, the places where our own knowledge, our own senses, our own capacities to see and imagine as another does, must fall. Consider what Deborah Bird Rose reports for instance of Yarralin embodiment:

my brother is equivalent to my right calf; my sister to my left calf. My right thigh is my mother's brother; my mother is my left thigh. My mother's mother and mother's mother's brother are my forehead (brain); my mother's father is my belly (indicating liver); my breast is my child (and sister's child), and my chin (whiskers) is my father. ${ }^{82}$

What body is this? It's not mine. I don't live in a body arranged thus. When I say that the death of a loved one means I've lost a part of myself, I don't feel it to be located in my right calf, or my thigh. Similarly, I don't know what the manngyin is for the Yarralin. Manngyin, as Bird Rose tells us, is connected to flesh and organs and when a person dies and is buried it gets up again!83 What strangeness is this? How do I signify it? Perhaps within the Western notion of spirit? It would be easy to start connoting these kinds of accounts of the living and the dead with Western notions of body and spirit, but to do so would surely mean that we have once more fallen into Western mind-body dichotomies and Western religious notions. As Bird Rose goes on to say, 'spirit' 'cannot but signal a body-soul dichotomy which is inappropriate to the Yarralin context'. ${ }^{44}$ Translation fails, and into the gap so easily slips our own vocabulary and generic codes: magic and superstition, myth and magic realism. We make others objects of knowledge 'magic' in a move that paradoxically tames and familiarises. 
To close, I turn to a highly personal account of contact with Indigenous 'magical' objects from another world that the cultural historian Tom Griffiths gives in Hunters and Collectors: The Antiquarian Imagination in Australia. 85 The story that Griffiths tells is about his experience of transporting Aboriginal artefacts to the State Library of Victoria but it might speak also of white readers of Carpentaria and our wishes to invest another's objects with magical powers, while divesting them of their difference:

Even parcelled in a dusty box they were, I suspected, still full of power ... During the long drive back to Melbourne I felt increasingly conscious of the boxes in the back of the station-wagon enclosing the secret/sacred objects. Whose were they? What meanings did they hold? What processes had brought them here, a process that now implicated me? I thought of a scene at the end of Raiders of the Lost Ark, a film about the archaeologistadventurer Indiana Jones, where the immensely powerful ark of the covenant is casually wheeled into the vaults of a state museum. Was I participating in the dispossession of a people and the disenchantment of the world? 86

Ken Gelder and Jane Jacobs have argued that the enchantment, power, and charisma that Griffiths feels these objects hold, and which perhaps are transmitted to Griffiths himself, occur not because of the place these objects have in their original world of meaning but because of their position now in Griffiths'.87 According to this view, the thrill Griffiths feels, then, would arise from his possession of these rare objects: from his power rather than theirs. The other's power is translated into a Hollywood cinematic version, a translation in which Griffiths figures as possessor of the other's magical power rather than possessed by it.

This is an ambivalent moment, for whatever pleasure we might recognise in this scene, pleasure is not all there is. The scene has its terrifying aspects, too. These magical objects from another world are so very proximate to Griffiths-they sit just behind his back in the small enclosed space of his car where he cannot see them but he reports feeling their power. This is not entirely benign, surely; these strange objects that seem to possess power? What might be truly terrifying in this scene is not the power that a white subject sees in the other's objects but what he cannot see, even if he were to crane his neck, look back over his shoulder. That is, what might be 
most unbearable before another's objects is one's own necessarily partial and imperfect vision.

Alison Ravenscroft teaches in the English Program at La Trobe University, Melbourne. Her book The Postcolonial Eye will be published in 2011.

\footnotetext{
-NOTES

${ }^{1}$ Alexis Wright, Carpentaria, Giramondo, Sydney, 2006, p. 1.

2 Joan Copjec, Read My Desire: Lacan against the Historicists, An October Book, MIT Press, Cambridge, Massachusetts; London, 1994, p. 18.

${ }_{3}^{3}$ Ian Syson, 'Uncertain Magic', Overland, no. 187, 2007, pp. 85-6; Francis Devlin-Glass, 'Alexis Wright's Carpentaria', Antipodes, vol. 21, no. 1, June 2007, pp. 82-4; Frances Devlin-Glass, 'Broken Songs and Ecology: Writing on the Gulf of Carpentaria', Táin, no. 44, pp. 28-9, and Francis Devlin-Glass, 'A Politics of the Dreamtime: Destructive and Regenerative Rainbows in Alexis Wright's Carpentaria', Australian Literary Studies, vol. 23, no. 4, 2008, pp. 392-407; Katharine England, 'Small-town Dreaming', Advertiser, 30 September 2006, p. W10; Jane Sullivan, 'From Here to Carpentaria', Age, 9 September 2006, p. 26; Anon., 'A Great Divide-New Fiction from Australia', The Economist, 3 March 2007, p. 382; Michael Fizgerald, 'Crossing the Gulf', Time International South Pacific edition, 2 October 2006, issue 39, p. 62. In Anon., 'Ambitious Prose Draws on Rich Tradition', Canberra Times, 23 July 2006, p. B4, Peter Pierce is quoted as saying:

Wright's argument is that she's trying to do Aboriginal magical-realism and use oral tradition ... It's a very bold effort and it's more or less successful. What people don't seem to realise is that one of the things she's doing is rewriting Xavier Herbert's [1938 novel] Capricornia as Carpentaria. Is it breaking new ground in some way? In some ways Carpentaria follows Capricornia.

${ }^{4}$ Devlin-Glass, 'Alexis Wright's Carpentaria', p. 84. Critics and reviewers, too, tend to nod respectfully in the direction of the publisher, Ivor Indyk, attributing to him a creative influence that is rarely credited to a publisher of white-signed texts. See for instance Peter Pierce, 'Once Again All Credit to Giramondo', Canberra Times, 23 July 2006 p. B4; Susan Wyndham, 'Undercover', Sydney Morning Herald, 30 June 2007; Anon, 'A Great Divide'; Jason Steger, 'Humanity's Voice Rises', Age, 23 June 2007, p. 2; Michael Fitzgerald, 'Crossing the Gulf'.
} 
${ }^{5}$ Michele Grossman is an important exception among reviewers. 'Risk, Roguery and Revelation', Australian, 4 October 2006, p. 10.

${ }^{6}$ In 'Uncertain Magic', Ian Syson raises his own experience of growing up as a white boy in Mt Isa as a basis for judging the text's powers.

7 I make the argument that in reading practices a racialised and gendered reader is (re)made, and potentially imperfectly so, in 'Who is the White Subject?', Australian Humanities Review, no. 42, August 2007.

8 Ian Syson, 'Uncertain Magic', p. 85:

I am left uncertain as to what to think of Carpentaria. Is it a rambling showing-off of Wright's undoubted literary skills? Is it a mere pastiche of good ideas? Is it a book that, despite what can be taken for flaws and impasses, ends up a pleasing and important document of our time? I just don't know. The fact that when reading I kept drawing comparisons with Patrick White's Tree of Man-especially in relation to the sense of satisfaction in having finished what felt like at Australian epic-leads me to believe the latter ... perhaps.

Don Anderson also admits to not knowing where either the book or he were going, but does not mistake this for a failure of the book. Instead he sees it as the result of his own 'self-fashioning as a white western reader, looking for linear narrative and realistic detail', in 'Bound for Glory', Bulletin, 12 June 2007, vol. 125, no. 24.

9 Devlin-Glass, 'Broken Songs and Ecology'. The same criticisms were made of Alexis Wright's first novel, Plains of Promise.

${ }^{10}$ Syson, Devlin-Glass and Davison each refer to the novel's magic realist qualities. Steger asks whether it is a form of 'indigenous magic realism'. 'Dream' is often used, for instance see Dart's review, 'Alexis' Book Helps Break the Mould', and Jane Sullivan, 'From Here to Carpentaria'. Syson uses the term 'dreamscape', Devlin-Glass 'magic' (in 'Broken Songs and Ecology'); Denise Carter refers to Indigenous 'lore', in 'Novel Idea Pays Off', Cairns Post, 18 August 2007, p. 35; 'Dreamtime belief' is used by Katharine England, 'Small-town Dreaming'; Liam Davison refers to 'Dreamtime legends, ancestral tales and biblical stories of epic proportions' in 'Phantasmagorical Tale Fills a Legendary Landscape', Sydney Morning Herald, 16 September 2006, p. 32.

${ }^{11}$ As Stephen Slemon has argued, magic realism might work as: one of the paradigmatic critical tropes for justifying an ignorance of the local histories behind specific textual practices and for securing first-world postmodernism's naturalization of ... that 'casual, unmoored international audience' which claims everything in the wide world as somehow its own.

Slemon, 'Magic Realism as Postcolonial Discourse' in Magic Realism: Theory, History, Community, edited and with an introduction by Lois Parkinson Zamora and Wendy B. Faris, Duke University Press, Durham and London, 1995, pp. 408-9. 
12 For examples, see Geoff Hancock's introduction to Hancock (ed.), Magic Realism, Aya Press, Toronto, pp. 7-15; Maggie Bowers, Magic(al) Realism: The New Critical Idiom, Routledge, London and New York, 2004; Amaryll Beatrice Chanady, Magical Realism and the Fantastic: Resolved Versus Unresolved Antinomy, Garland, New York, 1985. Zamora and Faris speak of the production of a third liminal space: 'The propensity of magical realist texts to admit a plurality of worlds means that they often situate themselves on liminal territory between or among these worlds.' Zamora and Faris (eds) , Magic Realism, p. 6.

13 Franz Roh, Realismo Mágico, post expressionismo: problemas de la pintura europa mas reciente, trans. (from the German) Fernando Vela, Madrid: Revista de Occidente, 1927. Roh's original work is NachExpressionismus, Magicher Realismus: Probleme der neuesten Europäischen Malerei, Leipzig, Klinkhardt and Biermann, 1925. Translated from Spanish to English by Wendy B. Faris 'Magical Realism: PostExpressionism', in Zamora and Faris (eds), Magic Realism, p. 16.

${ }^{14}$ Sigmund Freud, 'The Uncanny', in Penguin Freud Library, vol. 14. Art and Literature, General Editor, Angela Richards, trans. James Strachey, Penguin, Hammondsworth, England, 1976.

15 Maria Takolander associates what she calls others' superstitious beliefs with sub education.

Takolander, Catching Butterflies: Bringing Magical Realism to Ground, Peter Lang, Bern, 2007.

${ }^{16}$ Patrick Wolfe 'On Being Woken Up: The Dreamtime in Anthropology and in Australian Settler

Culture', Comparative Studies in Society and History, vol. 33, April 1991, pp. 197-224.

17 Wolfe, 'On Being Woken Up', p. 210.

18 Julia Kristeva uses this term to mean 'a permanent alternation: never the one without the other' in About Chinese Women, trans. Anita Barrows, Marion Boyars, London, 1977, p. 38.

19 Maggie Ann Bowers cites Roberto Gonzales Echevarría, 'Isla a su vuela fugitiva: Carpentier y el realismo mágico', Revista Iberoamericana, vol. 40, no. 86, p. 35, in Bowers, Magic(al) Realism, p. 91. ${ }^{20}$ Slemon, 'Magic Realism as Postcolonial Discourse', p. 407.

${ }^{21}$ Gabriel García Márquez and Vargos Llosa, La Novella en America Latina, Dialogo, Universidad Nacional de Ingenieria, Lima, 1967, p. 19, quoted in Bowers, Magic(al) Realism, p. 92. It is what Alexis Wright might also be insisting upon when holding reservations about the term's applicability to her own writing: 'Some people call the book magic realism but really in a way, it's an Aboriginal realism which carries all sorts of things.' Wright quoted by Dart, 'Alexis' Book Helps Break the Mould'.

22 Zamora and Faris (eds), Magic Realism.

${ }^{23}$ For example, Takolander's paraphrase of Carpentier causes other people's 'real' to be delusional, or 'marvellous' by which she means a kind of 'unreal'; 'marvelous [sic] phenomena that people believe to be real', in Catching Butterflies, p. 88.

${ }^{24}$ See Stephen Muecke's very different approach to modernity, indigeneity and innovation in Muecke, Ancient and Modern: Time, Culture and Indigenous Philosophy, University of NSW Press, Sydney, 2004. 
25 Toni Morrison, 'Rootedness: The Ancestor as Foundation' in Mari Evans (ed.), Black Women Writers, Anchor Books, New York, 1984, p. 342, and quoted in P. Gabrielle Foreman, 'Past-on Stories: History and the Magically Real, Morrison and Allende on Call', in Zamora and Faris (eds), Magic Realism, p. 342. ${ }^{26}$ Alexis Wright is quoted as saying that Carpentaria might be an example of Aboriginal realism by Dart, 'Alexis's Book Helps Break the Mould'.

${ }^{27}$ Morrison, quoted in Thomas LeClair, 'The Language must not Sweat', New Republic, 21 March, 1981, p. 25, and cited in Foreman, 'Past-on Stories', p. 300, my emphasis.

${ }^{28}$ Bowers distinguishes between magic realism which, as the term's inventor puts it refers to 'the mystery [that] does not descend to the represented world but rather hides and palpates behind it' and magical realism, understood by Salman Rushdie as the 'commingling of the improbable and the mundane', quoted in Bowers, Magic(al) Realism, p. 3.

${ }^{29}$ Slemon, 'Magical Realism as Postcolonial Discourse', p. 409.

${ }^{30}$ For an illuminating discussion of the skull in The Ambassadors from a Lacanian perspective, see Parveen Adams, The Emptiness of the Image: Psychoanalysis and Sexual Difference, Routledge, London and New York, pp. 109-21. For an important mobilisation for Australian literary criticism of Lacanian ideas on modern art and emptiness see Kate Foord, 'The Fantasy of the Modern Australian Nation: Travelling to the “Empty Centre”', Australian Feminist Studies, vol. 18, no. 42, 2003, pp. 273-83.

31 Bowers, Magic(al) Realism, p. 93.

32 Takolander explicitly argues against reading magical realism as a representation of another culture's reality, or 'marginal realism'. She argues against

many critics and writers of magical realism, including García Márquez, [who] have suggested that magical realist fiction is so relevant to its cultural origins as to be inherently specific and mimetically faithful to them. This is a ... prominent misconception about magical realist writing'. [Catching Butterflies, p. 17]

Takolander is not sympathetic to advocates of a Carpentierian theory of the magical margins who, in Camayd-Freixas' words, typically 'lean towards an ethnological version of Magical Realism', a magical realism that 'issues from an alternate world view one might call "primitive" ... which is unique to a particular "ethnic and cultural enclave"', Camayd-Freixas quoted in Takolander, Catching Butterflies, p. 159.

33 Takolander, Catching Butterflies, p. 170

${ }^{34}$ Bayles quoted in Takolander, Catching Butterflies, p. 170. Bayles continues: '[T]his attempt by Morrison to transform black folklore into painless enchantment comes dangerously close to reviving the spirit of antebellum nostalgia, updated as a Disney cartoon full of yam-spinning 'darkies' with droll names.' Bayles in Takolander, Catching Butterflies, p. 170.

35 This is a kind of writing that might be what Alejo referred to as lo real maravilloso which he distinguished from surrealism or the fantastic 'on the ground that it does not explore another or second reality, but rather amplifies the parameters of our present reality.' Quoted by Foreman, 'Past-on 
Stories', p. 298. In this sense, Carpentier might be taken to refer back to Roh, and the idea that the socalled magic is another aspect of reality; that is, Carpentier's claims would deliver the Indigenoussigned text into a notion of reality as always having these two parts.

36 Wright, Carpentaria, pp. 55-6.

37 Wright, Carpentaria, p. 58.

38 Wright, Carpentaria, p. 57.

${ }^{39}$ Wright, Carpentaria, p. 62.

${ }^{40}$ Wright, Carpentaria, p. 63, original emphasis.

${ }^{41}$ Wright, Carpentaria, pp. 82-3.

42 Wright, Carpentaria, p. 73.

${ }^{43}$ Wright, Carpentaria, p. 59.

${ }^{44}$ Wright, Carpentaria, p. 58.

45 Personal communication with the author. Capricornia and Carpentaria might, Alexis Wright suggests, be read productively together for the historical differences they figure.

46 Wright, Carpentaria, p. 276.

47 Wright, Carpentaria, p. 303.

48 Wright, Carpentaria, p. 467.

${ }^{49}$ According to Katharine England in 'Small-town Dreaming':

Norm Phantom, who has difficulty differentiating between dead and living visitors to his fish room, subscribes to a wonderful synthesis of scriptural Christianity and Dreamtime beliefs, and Will Phantom is calmly lectured during a town-razing cyclone by an impossible succession of beanie-clad elders.

For Jane Sullivan, too, in 'From Here to Carpentaria': the 'old people in beanies are more [Will's] hallucination than reality'.

${ }^{50}$ Wright, Carpentaria, p. 519.

51 Wright, Carpentaria, p. 186.

52 Wright, Carpentaria, p. 206.

53 Wright, Carpentaria, p. 209.

54 Wright, Carpentaria, p. 210.

55 Wright, Carpentaria, p. 119.

${ }^{56}$ Wright, Carpentaria, p. 144.

${ }^{57}$ Wright, Carpentaria, p. 119.

58 Wright, Carpentaria, p. 120.

59 Wright, Carpentaria, p. 226.

${ }^{60}$ Wright, Carpentaria, p. 228.

${ }^{61}$ Wright, Carpentaria, p. 343. 
62 Wright, Carpentaria, p. 344.

${ }^{63}$ In magic realism, the two parts, fantasy and realism, are described by Slemon as:

each working toward the creation of a different kind of fictional world from the other. Since the ground rules of these two worlds are incompatible, neither one can fully come into being, and each remains suspended, locked in a continuous dialectic with the 'other', a situation which creates disjunction within each of the separate discursive systems, rending them with gaps, silences and absences.

'Magic Realism as Postcolonial Discourse', p. 409.

${ }^{64}$ For discussion of Indigenous story popularised as children's story, see John Morton, 'Tiddalik's

Travels: The Making and Remaking of an Aboriginal Flood Myth', Advances in Ecological Research, vol.

39, 2006, pp. 139-58.

${ }^{65}$ Wolfe, 'On Waking Up'.

${ }^{66}$ Aboriginal writers become peddlers of a 'maban' reality which, according to Takolander, sits very close to a capitulation to the pressures of publishing houses' commercial interests, including the selling power of 'magic realism', rather than a representation of subjectivity that arises in another cultural location, Takolander, Catching Butterflies, p. 171. Takolander's confidence that the 'magical' events in magical realist novels do not arise from any cultural belief system (p. 201) - she cites the return of the dead child in Beloved as an example-puts another kind of pressure on reading Indigenous writing. The so-called maban or magic realist elements she finds in Indigenous women's lifestory for instance-she refers to Morgan, Ginibi, and Sykes-are dismissed. Takolander is not sympathetic to advocates of a Carpentierian theory of the magical margins who, in Camayd-Freixas' words, typically 'lean towards an ethnological version of Magical Realism', a magical realism that 'issues from an alternate world view one might call "primitive"', which is unique to a particular 'ethnic and cultural enclave', Camayd-Freixas quoted by Takolander, p. 159.

${ }^{67}$ Frances Devlin-Glass, 'A Politics of the Dreamtime', p. 392.

${ }^{68}$ Wright quoted in Katharine England and Deborah Bogle, 'Place of Hope and Desperation', Advertiser, 30 June 2007, p. W8.

${ }^{69}$ Deborah Bird Rose, Dingo makes us Human: Life and Land in Australian Aboriginal Culture, Cambridge University Press, Cambridge, 2000.

${ }^{70}$ Devlin-Glass, 'A Politics of the Dreamtime', p. 392.

${ }^{71}$ Wright, Carpentaria, p .2.

72 Wright, Carpentaria, pp. 1-2.

${ }^{73}$ Devlin-Glass, 'A Politics of the Dreamtime', p. 394.

${ }^{74}$ Devlin-Glass, 'A Politics of the Dreamtime', pp. 394-5.

${ }^{75}$ Alison Ravenscroft, 'Coming to Matter: The Grounds of Our Embodied Difference', Postcolonial Studies, vol. 10, no. 3, 2007, pp. 287-300.

${ }^{76}$ Devlin-Glass, 'A Politics of the Dreamtime', p. 397. 
${ }_{77}$ Devlin-Glass, 'A Politics of the Dreamtime', p. 394.

78 Wright cited by Sullivan, 'From Here to Carpentaria'.

79 Devlin-Glass, 'A Politics of the Dreamtime', p. 401.

${ }^{80}$ Deborah Bird Rose on the conception of the Law among the Yarralin of the Gulf of Carpentaria: 'Law is a serious life and death business for individuals and the world; it tells how the world hangs together. To disregard the Law would be to disregard the source of life and this is to allow the cosmos to fall apart.' Dingo Makes Us Human, p. 56.

81 Wright, Carpentaria, p.11. See Deborah Bird Rose's story about the law that is being in the ground in Dingo Makes Us Human, p. 56.

82 Bird Rose, pp. 58-9.

${ }^{83}$ Bird Rose, p. 71.

${ }^{84}$ Bird Rose, p. 58.

85 Tom Griffiths, Hunters and Collectors: The Antiquarian Imagination in Australia, Cambridge University Press, Cambridge and Melbourne, 1996.

86 Griffiths, Hunters and Collectors, pp. 278-9.

87 There is, they suggest, a 'dramatic articulation of charismatic power-charisma gained through these dusty objects, not because of their location in the "Aboriginal system" (their "authentic" location) but because of their position in the back of Griffiths' station-wagon'. Ken Gelder and Jane M. Jacobs, Uncanny Australia: Sacredness and Identity in a Postcolonial Nation, Melbourne University Press, Melbourne, 1998, p. 84. 